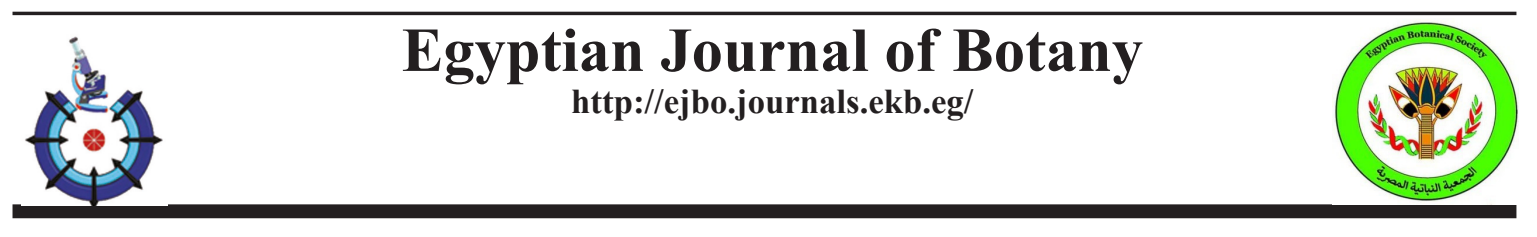

\title{
Screening for Tolerance-Resistance to Root-knot Nematode Meloidogyne incognita in Grafted and Ungrafted Cucurbit Rootstocks
}

\author{
Dina S.S. Ibrahim( ${ }^{(1) \#}$, M.H. Zaky ${ }^{(2)}$ \\ (1)Department of Nematodes Diseases and Central Lab of Biotechnology, Plant \\ Pathology Research Institute, Agricultural Research Center (ARC), 12619 Giza, Egypt; \\ ${ }^{(2)}$ Horticulture Research Institute, Agricultural Research Center (ARC), 12619 Giza, \\ Egypt.
}

\begin{abstract}
$\mathbf{T}$ HE CURRENT study aimed to screen eight ungrafted and grafted cucurbit rootstocks as well as melon Hybrid London genotype against root-knot nematode infection. Ungrafted and grafted rootstocks i.e. Nun 6001, Squash No3, Super Shintosa, Flixel Fort, Ferro RZ, Coplt, Bottle gourd were classified as tolerant to M. incognita infection whereas melon genotype Hybrid London and Pakistani Loof rootstock ranked as susceptible hosts. Grafted cucurbit rootstocks i.e. Nun 6001 and Ferro RZ, gave the higher plant survival rate and growth parameters compared to ungrafted ones and the rest of rootstocks and melon genotype. Number of galls, females, and egg masses of $M$. incongita were significantly suppressed in ungrafted and grafted rootstocks compared to melon plant Hybrid London. All the rootstocks differed in their ability to stimulate peroxidase (PO), polyphenol oxidase (PPO) activities, and phenol content. The study revealed that grafting melon plants onto all the previous tolerant rootstocks is an effective tool that may enable the susceptible melon scion to tolerate $M$. incognita which leads to an increase in plant survival rate and growth parameters.
\end{abstract}

Keywords: Melon, Peroxidase, Root-knot nematode, Rootstocks, Survival rate.

\section{Introduction}

Root-knot nematode (Meloidogyne incognita) is a critical pest of cultivated melon (Cucumis melo) in Egypt and severe crop damage especially in light soils (Abd-Elgawad \& Aboul-Eid, 2001; AbdElgawad, 2008; EL-Mesalamy et al., 2020). Rootknot nematodes cause dramatic galling on the roots of host plants, and even low nematode levels can cause high yield losses (Sasser et al., 1983; Amin, 1993). Root-knot nematodes can also enhance the severity of soil-borne diseases for example fungal wilt in cucurbit crops caused by Fusarium (Wang \& Roberts, 2006; Talavera et al., 2012; López-Gómez et al., 2016). M. incognita is the most predominant species of those infecting cucurbitaceous plants such as melon (Cucumis melo), watermelon (Citrullus lanatus), and cucumber (C. sativus) in
Egypt. No commercial melon cultivars are known to be resistant to root-knot nematodes (Siguenza et al., 2005; López-Gómez et al., 2016; Ayala-Doñas et al., 2020).

The major method for controlling root-knot nematodes in melon and other cucurbit crops is soil fumigation and other nematicides. However, since methyl bromide is banned, farmers are searching for alternative control methods. A potential solution is grafting melon sections onto tolerant or resistant rootstocks (Siguenza et al., 2005; Liu et al., 2020).

Most grafting literature on soil-borne diseases reported that grafting can induce resistance or tolerance to various soil-borne pathogens as fungal, bacterial, and nematodes (Penelope, 2008; Aslam, et al., 2020, Ayala-Doñas et al., 2020, Thakur \&

\#Corresponding author email: mickeyocean@yahoo.com $0000-0003-4672-4568$

Received 12/11/2020; Accepted 4/4/ 2021

DOI: $10.21608 /$ ejbo.2021.46903.1572

Edited by: Prof. Dr.: Khaled M. Ghanem, Department of Botany and Microbiology, Faculty of Science, Alexandria University, Alexandira, Egypt.

C2021 National Information and Documentation Center (NIDOC) 
Savita, 2020). Therefore, the primary motive for grafting cucurbits is improving vigor and tolerance to abiotic stress and resistance to soil-borne pests and pathogens when genetic or chemical approaches for disease management are not available (Oda, 2002a $\& b$; Thakur et al., 2020). Moreover, identifying root-knot-resistant rootstocks would introduce an economical and eco-friendly approach for managing root-knot nematodes in melon (Thies et al., 2010).

Grafting a susceptible scion onto a resistant rootstock can create resistance to a cultivar without prolonged screening as well as selection required to breed for resistance into a cultivar (Liu et al., 2020). Grafting melon on resistant or tolerant cucurbits rootstocks led to reduced nematode gall formation (Siguenza et al., 2005; Kokalis-Burelle \& Rosskopf, 2011).

In some cases, the rootstocks induce tolerance contingent on the extensive root system and vigor (Giannakou \& Karpouzas, 2003; Miguel et al., 2005), but some rootstocks possess genetic resistance that is appeared in the grafted plants (Hagitani \& Toki, 1978; Siguenza et al., 2005; Gu et al., 2006). Moreover, Biles et al. (1989) reported that substances related to soil-borne pathogen tolerance are formed in the roots of the rootstocks then translocated to the scion through the xylem in grafted cucurbits plants. Grafted plants showed more leaves, larger leaf area, thicker main stem diameter (Lee \& Oda, 2003; Yetisir \& Sari, 2003) comparing with the control. Grafted plants were more vigorous with remarkably higher yields compared to non-grafted plants (Paroussi et al., 2007).

Therefore this study aimed to screen several commercial and wild cucurbit rootstocks used in grafting as suitable rootstocks to provide resistance or tolerance to Meloidogyne incognita and improve the productivity of melon.

\section{Materials and Methods}

This study was conducted in a greenhouse at the Department of Nematodes Plant Diseases, Agricultural Research Center (ARC), Giza during the two successive seasons i.e., 20/8/2015 and $22 / 8 / 2016$. This study aimed to screen eight cucurbit rootstocks, and melon (Cucumis melo) " Hybrid London (Galia type)" genotypes for tolerance against the root-knot nematode Meloidogyne incognita. Melon cultivar, as a scion, and the tested rootstocks were listed (Table 1).

\section{Meloidogyne incognita inoculum}

Second stage juveniles of M.incognita were obtained from a single egg mass propagated on roots of coleus plant (Coleus blumei L.) for three months under the greenhouse conditions at Nematological Research Unit (NERU), Plant Pathology Research Institute, Giza, Egypt. A sodium hypochlorite $(\mathrm{NaOCl})$ extraction technique (Hussey \& Barker, 1973) was used for the collection of eggs of $M$. incognita. Infected roots were gently washed with tap water and cut into small segments. Root segments were then shacked in $200 \mathrm{~mL}$ of $1.0 \%$ $\mathrm{NaOCl}$ solution for $1-2 \mathrm{~min}$. $\mathrm{NaOCl}$ solution was passed through a 60-mesh sieve nested over a 400mesh sieve to separate freed eggs. A 400-mesh sieve with eggs was quickly placed under a stream of tap water for removing residual $\mathrm{NaOCl}$ and collected. The remaining roots were rinsed using water to remove additional eggs and then collected. Eggs were then placed in a Petri dish with a sufficient amount of water and left for incubation for 3-4 days.

TABLE 1. Melon cultivar and cucurbit rootstocks used in this experiment

\begin{tabular}{lccc}
\hline Plants & Genotypes & Species & Seed production company \\
\hline Melon (Scion) & Hybrid London ME & Cucumis melo L. & Rijk Zwaan \\
\hline Squash No3 & Cucurbita maxima & Sakata \\
& Super Shintoza & Cucurbita maxima $\times$ C. moschata & G.S.I \\
& FliexFort & Cucurbita maxima $\times$ C. moschata & Enza Zaaden \\
Rootstocks & Ferro RZ & Cucurbita maxima $\times$ C. moschata & Rijk Zwaan \\
& Nun 6001 & Cucurbita maxima $\times$ C. moschata & Nunhium \\
& Coplt & Cucurbita maxima $\times$ C. moschata & Rijk Zwaan \\
$*$ Bottle gourd & Lagenaria siceraria & Pakistan
\end{tabular}

*HRI: Horticultural Research Institute 


\section{Experimental design}

Grafted rootstocks

Eight cucurbit rootstocks and melon 'Hybrid London' (C) seeds were sown in plug trays (cell volume: $50 \mathrm{~mL}$ ) contained peat moss and vermiculite mixture in a ratio of $1: 1(\mathrm{v} / \mathrm{v})$ under greenhouse to produce seedlings. Melon seedlings (17 days old) were then grafted onto the previous rootstocks by splice method according to Hassell et al. (2008). Grafted rootstocks (25 days old), as well as melon seedlings, were separately transplanted in plastic pots $(25 \mathrm{~cm}$ -d) filled with $2 \mathrm{~kg}$ sterilized clay-sand soil (1:1) (v:v).

\section{Ungrafted rootstocks}

Eight cucurbit rootstocks genotypes and melon 'Hybrid London' C seeds (2 seeds/pot) were sown in sterilized clay-sand soil $(1: 1)(\mathrm{v}: \mathrm{v})$ as previously mentioned.

Grafted and ungrafted rootstocks, as well as melon seedlings, were inoculated with 1000 J2 M. incognita after four and seven days of planting, respectively. Eight pots were used for each plant cultivar genotype, and half of them were inoculated with nematode. While the other eight pots for each cultivar were left without nematode inoculum and served as control. All pots were arranged in a Completely Randomised Block Design system and horticultural treated the same under greenhouse conditions for two seasons 2015 and 2016.

\section{Recorded data}

After fifty-five days from nematode inoculation and seventy-five days from planting grafted melon seedlings, plant survival rates were measured by dividing the numbers of the successful plants by the total number of the plants. Moreover, plants were uprooted and root systems were washed from the soil. Length and fresh weight of shoot and root and shoot dry weight was measured and percent reduction in such growth parameters was calculated concerning healthy plants. The number of juveniles $\left(\mathrm{J}_{2}\right)$ in soil /pot, galls, egg masses, and females per root system were counted and recorded. The infected roots were stained using acid fuchsin (Byrd et al., 1983), washed with tap water, and placed in pure cold glycerin (Goodey, 1957) to facilitate the counting.

After clearing, numbers of endo-parasitic forms were determined with the aid of a stereomicroscope. The nematode reproduction ( $\mathrm{R}$ factor) for each cultivar or rootstocks was calculated by dividing the final nematode population (Pf) by the initial nematode population (Pi). Root gall index (RGI) and egg mass index (EI) were determined and recorded as follows: $0=$ no galls or egg masses, $1=1-2$ galls or egg masses, $2=3-10$ galls or egg masses, $3=11-30$ galls or egg masses, $4=31-100$ galls or egg masses and $5=$ more than 100 galls or egg masses, according to the described scale by Taylor \& Sasser (1978).

Host suitability was measured based on the relation between root gall index (RGI) and nematode reproduction (RF) according to Canto- Saenz (1983) as follows: $(\mathrm{RGI} \leq 2 \& \mathrm{R} \leq 1)$ resistant $(\mathrm{R}),(\mathrm{RGI} \leq 2 \& \mathrm{R} \geq 1)$ tolerant $(\mathrm{T})$, and ( $R G I \geq 2 \& R \geq 1$ ) susceptible (S).

Total phenol content in leaves of rootstocks infested with $M$. incognita was determined and compared to uninfected control plants. Also, enzyme peroxidase (PO) and polyphenol oxidase (PPO) were determined in the fresh leaves of cucurbit rootstocks infected with $M$. incognita compared to control plants.

\section{Statistical analysis}

All obtained data were statistically analyzed according to the Randomized Complete Block Design in factorial arrangement using Duncan's Multiple Range Test at 5\% level to compare between treatment means as described by Gomez \& Gomez (1984).

\section{Results}

\section{Plant survival rate}

Results in Tables 2 show the plants' survival rate for ungrafted and grafted rootstocks and melon genotypes in soil inoculated with $M$. incognita. Nun 6001, Squash No3, Super Shintosa, Flixel Fort, Ferro RZ, Coplt, and Bottle gourd rootstocks showed a higher plant survival rate than the Pakistani Loof rootstock and melon genotype during the two studied seasons (Table 2). Grafted melon onto all the previous rootstocks showed also a higher plant survival rate than the grafted melon plant onto Pakistani Loof rootstock or un-grafted melon plants during the two studied seasons (Table 2). 


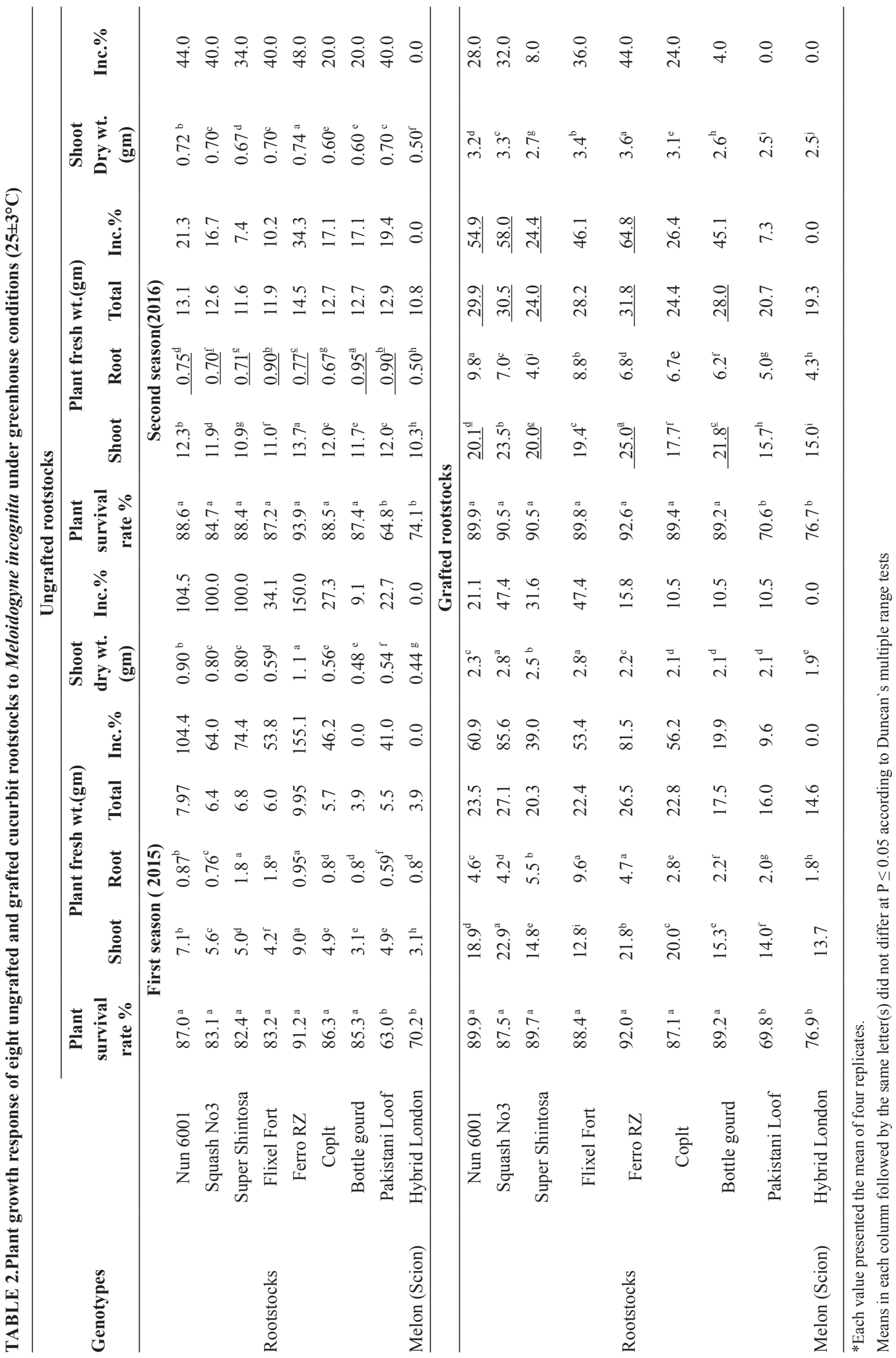

Egypt. J. Bot. 61, No. 2 (2021) 
The influence of $M$. incognita infection on growth parameters

Results reported in Table 2 indicated that the influence of $M$. incognita infection on growth parameters of ungrafted and grafted rootstocks and melon, Hybrid London under greenhouse conditions. Growth parameters of ungrafted and grafted cucurbit rootstocks were significantly increased compared to melon genotype grown in soil inoculated with M.incognita to a various extent (Table 2). Shoot dry weights of ungrafted rootstocks of Nun 6001 and Ferro RZ showed better improvement than those of grafted ones for the two seasons. Whereas, plant fresh weights of such rootstocks were significantly increased in the first season.

The highest values of growth parameters (total plant fresh weight and shoot dry weight) were recorded with grafted melon seedlings onto Ferro and Squash No3 at the first ansd second seasons by $81.5,85.6 ; 15.8,47.4$ and $64.8,58.0 ; 44.0$, 32.0 , respectively (Table 2). However, the lowest percentage values on growth parameters (total plant fresh weight and shoot dry weight) were recorded with grafted melon seedlings onto Pakistan Loof rootstock at the first and second seasons by $9.6 \&$ $10.5 \%$ and $7.3 \& 0.0 \%$, respectively. Also, the tested melon genotype (Hybrid London) showed the lowest percentage value of most parameters of total plant fresh weight and shoot dry weight at the first and second seasons.

Host suitability of the tested rootstocks to $M$. incognita infection

Most of the studied rootstocks either grafted or ungrafted i.e. Nun 6001, Squash No3, Super Shintosa, Flixel Fort, Ferro RZ, Coplt, and Bottle gourd significantly $(\mathrm{P} \geq 0.05)$ decreased the number of galls, females, and egg masses during the first and second season (Tables 3,4) compared with melon "Hybrid London".

According to the scale described by Canto- Saenz (1983) based on the relationships between root gall index (RGI) and R factor, all ungrafted rootstocks except Pakistani Loof and melon Hybrid London were rated as tolerant hosts at the first and second season. Root gall index ranged from 2.0 to 3.0 for both seasons while the $\mathrm{R}$ factor ranged from 0.39 to 0.66 and from 0.34 to 0.78 for the first and second seasons, respectively (Table 3 ). Conversely grafted or ungrafted Pakistan loof rootstock was recorded as a susceptible host to $M$. incognita at two studied seasons (Tables 3, 4). From the same tables, the tested melon (Hybrid London) was highly infected with $M$. incognita and ranked as a susceptible host with no significant differences in the two studied seasons.

Enzyme peroxidase and polyphenol oxidase contents

Data presented in Table 5 revealed that all rootstocks infected with $M$. incognita differed in their ability to stimulate peroxidase (PO) and polyphenol oxidase (PPO) activities. Both PO and PPO activities were lower in grafted and ungrafted Pakistani Loof rootstock infected with $M$. incognita in the first and second seasons.

\section{Phenol content}

Total phenol evaluated in leaves of rootstocks and grafted melon grown in soil infested with $M$. incognita revealed a moderate enhancement compared to melon plants (Table 5). All rootstocks showed a noticeable reduction in total phenol to various extents compared to non-inoculated plants. However, the least reduction in total phenol was recorded with ungrafted Pakistani Loof rootstocks $(29.4 \%)$ in the first season. Meanwhile, Flixel Fort rootstock $(6.3 \%)$ induced the least reduction in the second season compared with melon plants. On the other hand, grafted Pakistani Loof $(13.8,5.0 \%)$ recorded the lowest rank in total phenol at the first and second seasons comparing with melon, Hybrid London respectively.

\section{Discussion}

The present study showed that the commercial cultivar melons (Hybrid London) ranked as susceptible host to root-knot nematode, M.incognita that leads to a decrease in plant survival rate, growth parameters, activities of PO and PPO, total phenol, and increased the number of galls, females, and egg masses. These results agree with Siguenza et al. (2005), Mukhtar et al. (2013), and López-Gómez et al. (2016) who reported that no commercial cultivation melons are known to be resistant to rootknot nematode.

Out of eight rootstocks, melon grafted onto Ferro rootstock seedlings gave the highest percentage values of total plant fresh weight and shoot dry weight of cucurbits in the first season and second season. The results also showed that none of the eight tested rootstocks were immune or highly resistant to $M$. incognita infection. These results agree with Giné et al. (2017) who reported that the rootstock (Cucurbita maxima $\times$ C. moschata) was not resistant to $M$. incognita. 
TABLE 3. Development and reproduction of Meloidogyne incognita and relative susceptibility of ungrafted rootstocks under greenhouse conditions $\left(25 \pm 3^{\circ} \mathrm{C}\right)$

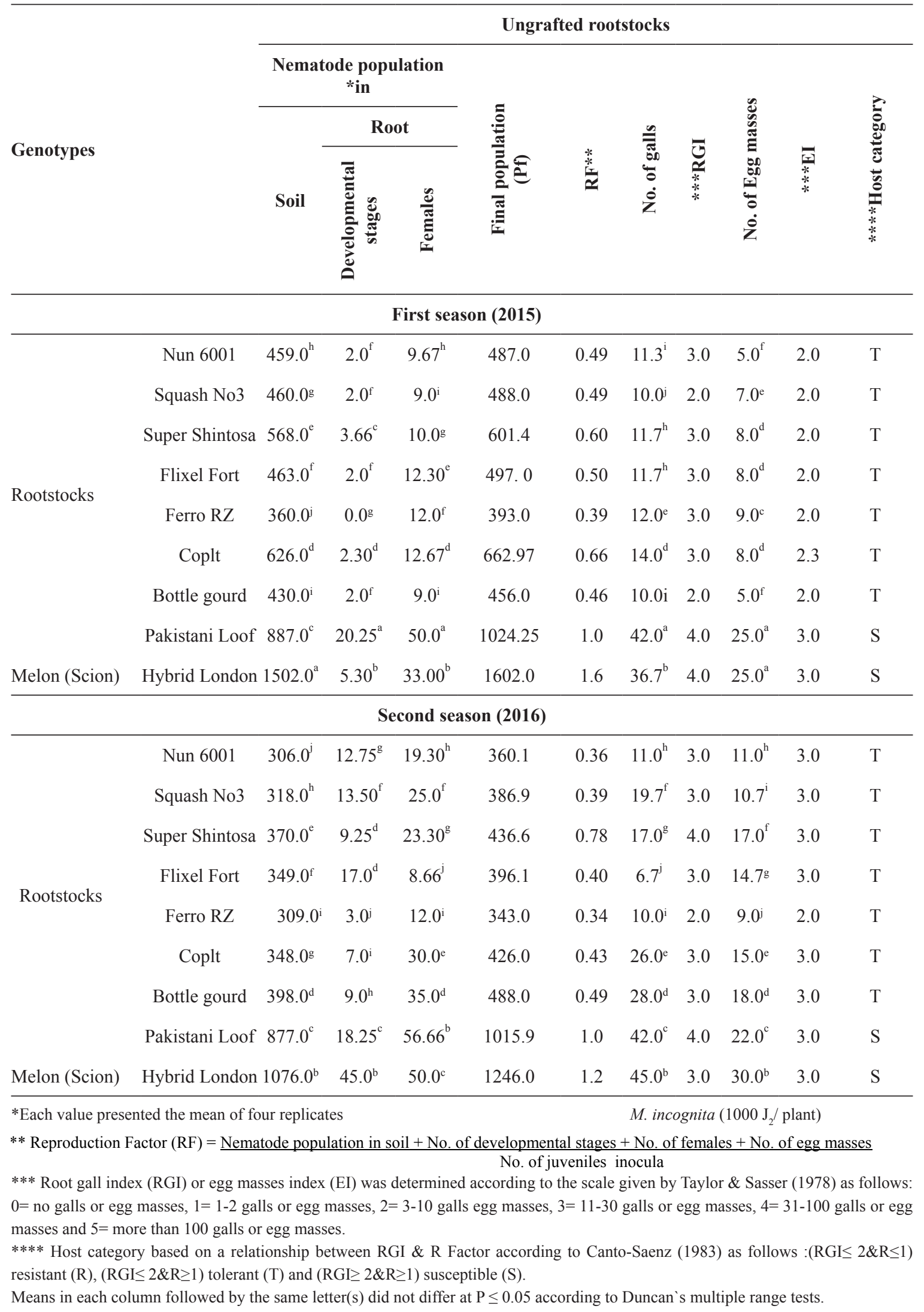


TABLE 4. Development, reproduction of Meloidogyne incognita, and relative susceptibility of grafted rootstocks under greenhouse conditions $\left(25 \pm 3^{\circ} \mathrm{C}\right)$

\section{Grafted rootstocks}

\section{Nematode population in*}

Genotypes

\begin{tabular}{|c|c|c|c|c|c|c|c|c|c|c|}
\hline & \multicolumn{10}{|c|}{ First season (2015) } \\
\hline \multirow{8}{*}{ Rootstocks } & Nun 6001 & $361.2^{\mathrm{h}}$ & $0.0^{\mathrm{c}}$ & $19.5^{\mathrm{h}}$ & 411.0 & 0.41 & $18.0^{\mathrm{e}}$ & 3.0 & $13.0^{\mathrm{f}} \quad 3.0$ & $\mathrm{~T}$ \\
\hline & Squash No3 & $380.0^{\mathrm{g}}$ & $0.0^{c}$ & $14.0^{\mathrm{k}}$ & 414.0 & 0.41 & $12.0^{\mathrm{h}}$ & 3.0 & $8.0^{j} \quad 2.0$ & $\mathrm{~T}$ \\
\hline & Super Shintosa & $372.5^{\mathrm{d}}$ & $0.0^{\mathrm{c}}$ & $20.5^{\mathrm{e}}$ & 426.6 & 0.43 & $19.3^{\mathrm{d}}$ & 3.0 & $14.3^{\mathrm{e}} 3.0$ & $\mathrm{~T}$ \\
\hline & Flixel Fort & $388.5^{\mathrm{e}}$ & $0.0^{\mathrm{c}}$ & $21.3^{\mathrm{d}}$ & 444.3 & 0.44 & $20.0^{c}$ & 3.0 & $14.5^{\mathrm{d}} 3.0$ & $\mathrm{~T}$ \\
\hline & Ferro RZ & $299.5^{\mathrm{i}}$ & $0.0^{\mathrm{c}}$ & $15.8^{\mathrm{j}}$ & 339.9 & 0.34 & $13.8^{\mathrm{g}}$ & 3.0 & $11.3^{\mathrm{h}} \quad 3.0$ & $\mathrm{~T}$ \\
\hline & Coplt & $385.0^{\mathrm{f}}$ & $0.0^{\mathrm{c}}$ & $16.0^{\mathrm{i}}$ & 525.6 & 0.53 & $14.0^{\mathrm{f}}$ & 3.0 & $11.0^{\mathrm{i}} 3.0$ & $\mathrm{~T}$ \\
\hline & Bottle gourd & $390.0^{\mathrm{d}}$ & $0.0^{\mathrm{c}}$ & $20.0^{\mathrm{f}}$ & 442.0 & 0.44 & $20.0^{\mathrm{c}}$ & 3.0 & $12.0^{\mathrm{g}} \quad 3.0$ & $\mathrm{~T}$ \\
\hline & Pakistani Loof & $399.5^{\mathrm{c}}$ & $1.3^{\mathrm{a}}$ & $22.5^{\mathrm{c}}$ & 459.5 & 0.46 & $20.5^{\mathrm{b}}$ & 3.0 & $17.5^{\mathrm{b}} 3.0$ & $\mathrm{~S}$ \\
\hline \multirow[t]{2}{*}{ Melon (Scion) } & Hybrid London & $447.0^{\mathrm{a}}$ & $1.0^{\mathrm{b}}$ & $33.7^{\mathrm{a}}$ & 525.3 & 0.53 & $25.3^{\mathrm{a}}$ & 3.0 & $18.3^{\mathrm{a}} 3.0$ & $\mathrm{~S}$ \\
\hline & \multicolumn{10}{|c|}{ Second season (2016) } \\
\hline \multirow{8}{*}{ Rootstocks } & Nun 6001 & $301.0^{\mathrm{h}}$ & $0.0^{\mathrm{a}}$ & $20.0^{\mathrm{f}}$ & 356.0 & 0.36 & 20.0 & 3.0 & $15.0^{\mathrm{c}} \quad 3.0$ & $\mathrm{~T}$ \\
\hline & Squash No3 & $330.0^{\mathrm{g}}$ & $0.0^{\mathrm{a}}$ & $25.0^{\mathrm{a}}$ & 385.0 & 0.39 & 20.0 & 3.0 & $10.0^{\text {h }} 3.0$ & $\mathrm{~T}$ \\
\hline & Super Shintosa & $347.5^{f}$ & $0.0^{\mathrm{a}}$ & $21.0^{\mathrm{e}}$ & 403.1 & 0.40 & $26.3^{\mathrm{d}}$ & 3.0 & $11.8^{\mathrm{f}} \quad 3.0$ & $\mathrm{~T}$ \\
\hline & Flixel Fort & $349.0^{\mathrm{e}}$ & $0.0^{\mathrm{a}}$ & $20.0^{\mathrm{g}}$ & 399.0 & 0.40 & 20.0 & 3.0 & $10.0^{\mathrm{h}} 3.0$ & $\mathrm{~T}$ \\
\hline & Ferro RZ & $279.5^{\mathrm{f}}$ & $0.0^{\mathrm{a}}$ & $15.0^{\mathrm{h}}$ & 319.0 & 0.32 & $14.3^{\mathrm{e}}$ & 3.0 & $11.5^{\mathrm{g}} \quad 3.0$ & $\mathrm{~T}$ \\
\hline & Coplt & $362.5^{\mathrm{d}}$ & $0.0^{\mathrm{a}}$ & $21.3^{\mathrm{e}}$ & 424.9 & 0.42 & $28.3^{\mathrm{c}}$ & 3.0 & $12.8^{\mathrm{f}} 3.0$ & $\mathrm{~T}$ \\
\hline & Bottle gourd & $360.5^{\mathrm{e}}$ & $0.0^{\mathrm{a}}$ & $12.5^{\mathrm{i}}$ & 425.5 & 0.43 & $31.5^{\mathrm{f}}$ & 3.0 & $21.0^{\mathrm{b}} \quad 3.0$ & $\mathrm{~T}$ \\
\hline & Pakistani Loof & $400.5^{\mathrm{a}}$ & $0.0^{\mathrm{a}}$ & $24.8^{\mathrm{b}}$ & 471.4 & 0.47 & $23.8^{\mathrm{a}}$ & 3.0 & $22.3^{\mathrm{a}} 3.0$ & $\mathrm{~S}$ \\
\hline Melon (Scion) & Hybrid London & $384.5^{\mathrm{b}}$ & $0.0^{\mathrm{a}}$ & $21.8^{\mathrm{d}}$ & 449.3 & 0.45 & $28.5^{\mathrm{b}}$ & 3.0 & $14.5^{\mathrm{d}} 3.0$ & $\mathrm{~S}$ \\
\hline
\end{tabular}

*Each value presented the mean of four replicates

M. incognita $\left(1000 \mathrm{~J}_{2} /\right.$ plant $)$

** Reproduction Factor $(\mathrm{RF})=$ Nematode population in soil + No. of developmental stages + No. of females + No. of egg masses No. of juveniles inocula

*** Root gall index (RGI) or egg masses index (EI) was determined according to the scale given by Taylor\& Sasser (1978) as follows: $0=$ no galls or egg masses, $1=1-2$ galls or egg masses, $2=3-10$ galls egg masses, $3=11-30$ galls or egg masses, $4=31-100$ galls or egg masses and $5=$ more than 100 galls or egg masses.

**** Host category based on a relationship between RGI \& R Factor according to Canto-Saenz (1983) as follows :(RGI $\leq 2 \& \mathrm{R} \leq 1)$ resistant $(\mathrm{R}),(\mathrm{RGI} \leq 2 \& \mathrm{R} \geq 1)$ tolerant $(\mathrm{T})$ and $(\mathrm{RGI} \geq 2 \& \mathrm{R} \geq 1)$ susceptible $(\mathrm{S})$.

Means in each column followed by the same letter(s) did not differ at $\mathrm{P} \leq 0.05$ according to Duncan`s multiple range tests. 
TABLE 5. Enzyme activities and total phenol in fresh leaves of rootstocks grown in soil infected with Meloidogyne incognita under greenhouse conditions

\begin{tabular}{|c|c|c|c|c|c|c|c|c|c|c|c|c|c|}
\hline \multirow{3}{*}{ Cultivars } & & \multicolumn{6}{|c|}{ Ungrafted rootstocks } & \multicolumn{6}{|c|}{ Grafted rootstocks } \\
\hline & & PO & $\begin{array}{c}\% \\
\text { Dec. }\end{array}$ & PPO & $\begin{array}{c}\% \\
\text { Dec. }\end{array}$ & $\begin{array}{c}\text { T. } \\
\text { Phenol }\end{array}$ & $\begin{array}{c}\% \\
\text { Dec. }\end{array}$ & PO & $\begin{array}{c}\% \\
\text { Dec. }\end{array}$ & PPO & $\begin{array}{c}\% \\
\text { Dec. }\end{array}$ & $\begin{array}{c}\text { T. } \\
\text { Phenol }\end{array}$ & $\begin{array}{c}\% \\
\text { Dec. }\end{array}$ \\
\hline & & \multicolumn{6}{|c|}{ First season (2015) } & \multicolumn{6}{|c|}{ First season (2016) } \\
\hline \multirow{8}{*}{ Rootstocks } & Nun 6001 & $0.506^{\mathrm{i}}$ & 15.4 & $0.029^{i}$ & 73.0 & $0.420^{\mathrm{i}}$ & 53.2 & $0.537^{\mathrm{i}}$ & 9.6 & $0.021^{\mathrm{g}}$ & 53.3 & $0.423^{\mathrm{i}}$ & 37.3 \\
\hline & Squash No3 & $0.509^{\mathrm{h}}$ & 14.9 & $0.037^{\mathrm{h}}$ & 66.7 & $0.425^{\mathrm{h}}$ & 52.6 & $0.546^{\mathrm{h}}$ & 8.1 & $0.023^{\mathrm{f}}$ & 48.9 & $0.446^{\mathrm{h}}$ & 33.9 \\
\hline & $\begin{array}{c}\text { Super } \\
\text { Shintosa }\end{array}$ & $0.546^{\mathrm{d}}$ & 8.7 & $0.065^{\mathrm{g}}$ & 41.4 & $0.564^{\mathrm{d}}$ & 37.1 & $0.567^{\mathrm{f}}$ & 4.5 & $0.031^{\mathrm{e}}$ & 31.0 & $0.457^{\mathrm{g}}$ & 32.3 \\
\hline & Flixel Fort & $0.511^{\mathrm{g}}$ & 14.5 & $0.073^{\mathrm{f}}$ & 34.2 & $0.458^{\mathrm{f}}$ & 48.9 & $0.565^{\mathrm{g}}$ & 4.9 & $0.031^{\mathrm{e}}$ & 31.0 & $0.465^{\mathrm{f}}$ & 31.1 \\
\hline & Ferro RZ & $0.499^{j}$ & 16.6 & $0.024^{\mathrm{j}}$ & 78.4 & $0.413^{\mathrm{j}}$ & 54.0 & $0.524^{j}$ & 11.8 & $0.015^{\mathrm{h}}$ & 66.7 & $0.417^{\mathrm{j}}$ & 38.2 \\
\hline & Coplt & $0.523^{\mathrm{f}}$ & 12.5 & $0.089^{\mathrm{d}}$ & 19.8 & $0.470 \mathrm{e}$ & 47.6 & $0.577^{\mathrm{d}}$ & 2.9 & $0.032^{\mathrm{d}}$ & $\underline{28.9}$ & $0.566^{\mathrm{e}}$ & 16.1 \\
\hline & Bottle gourd & $0.534^{\mathrm{e}}$ & 10.7 & $0.087^{\mathrm{e}}$ & 21.6 & $0.446^{\mathrm{g}}$ & 50.3 & $0.576^{\mathrm{e}}$ & 3.0 & $0.038^{\mathrm{c}}$ & 15.6 & $0.571^{\mathrm{d}}$ & 15.4 \\
\hline & $\begin{array}{l}\text { Pakistani } \\
\text { Loof }\end{array}$ & $0.578^{\mathrm{c}}$ & 3.3 & $0.097^{\mathrm{c}}$ & 12.6 & $0.633^{c}$ & 29.4 & $0.580^{c}$ & 2.4 & $0.042^{b}$ & $\underline{6.7}$ & $0.582^{c}$ & 13.8 \\
\hline \multirow[t]{5}{*}{$\begin{array}{l}\text { Melon } \\
\text { (Scion) }\end{array}$} & $\begin{array}{l}\text { Hybrid } \\
\text { London }\end{array}$ & $0.598^{\mathrm{a}}$ & 0.0 & $0.111^{\mathrm{a}}$ & 0.0 & $0.897^{\mathrm{a}}$ & 0.0 & $0.594^{\mathrm{a}}$ & 0.0 & $0.045^{\mathrm{a}}$ & $\underline{0.0}$ & $0.675^{\mathrm{a}}$ & 0.0 \\
\hline & & \multicolumn{6}{|c|}{ Second season (2015) } & \multicolumn{6}{|c|}{ Second season (2016) } \\
\hline & Nun 6001 & $0.569^{\mathrm{h}}$ & 6.3 & $0.067^{\mathrm{i}}$ & 63.8 & $0.340^{\mathrm{h}}$ & 40.0 & $0.544^{\mathrm{h}}$ & 7.2 & $0.033^{\mathrm{g}}$ & 36.5 & $0.423^{\mathrm{d}}$ & 7.6 \\
\hline & Squash No3 & $0.578^{\mathrm{g}}$ & 4.8 & $0.077^{\mathrm{h}}$ & 58.4 & $0.357^{\mathrm{e}}$ & 37.0 & $0.554^{\mathrm{h}}$ & 5.5 & $0.036^{\mathrm{f}}$ & 30.8 & $0.345^{\mathrm{i}}$ & 24.7 \\
\hline & $\begin{array}{c}\text { Super } \\
\text { Shintosa }\end{array}$ & $0.588^{\mathrm{d}}$ & 3.1 & $0.112^{g}$ & 39.5 & $0.432^{\mathrm{d}}$ & 23.8 & $0.555^{\mathrm{g}}$ & 5.3 & $0.044^{\mathrm{e}}$ & 15.4 & $0.350^{\mathrm{h}}$ & 23.6 \\
\hline \multirow{5}{*}{ Rootstocks } & Flixel Fort & $0.597^{\mathrm{c}}$ & 1.6 & $0.152^{\mathrm{e}}$ & 17.8 & $0.531^{\mathrm{c}}$ & 6.3 & $0.561^{\mathrm{f}}$ & 4.3 & $0.036^{\mathrm{f}}$ & 30.8 & $0.398^{\mathrm{g}}$ & 13.1 \\
\hline & Ferro RZ & $0.560^{\mathrm{i}}$ & 7.7 & $0.065^{\mathrm{j}}$ & 64.9 & $0.312^{\mathrm{j}}$ & 45.0 & $0.522^{\mathrm{i}}$ & 10.9 & $0.026^{\mathrm{h}}$ & 50.0 & $\underline{0.320^{\mathrm{i}}}$ & 30.1 \\
\hline & Coplt & $0.579^{f}$ & 4.6 & $0.115^{\mathrm{f}}$ & 37.8 & $0.356^{\mathrm{f}}$ & 37.2 & $0.565^{\mathrm{e}}$ & 3.5 & $0.048^{\mathrm{d}}$ & 7.7 & $\underline{0.399} \underline{\underline{f}}$ & 12.9 \\
\hline & Bottle gourd & $0.589^{d}$ & 3.0 & $0.165^{\mathrm{d}}$ & 10.8 & $0.342^{\mathrm{g}}$ & 39.7 & $0.569^{\mathrm{d}}$ & 2.9 & $0.048^{\mathrm{d}}$ & 7.7 & ${\underline{0.412^{\mathrm{e}}}}^{\underline{ }}$ & 10.0 \\
\hline & $\begin{array}{l}\text { Pakistani } \\
\text { Loof }\end{array}$ & $0.597^{\mathrm{c}}$ & 1.6 & $0.166^{c}$ & 10.3 & $0.327^{\mathrm{i}}$ & 42.3 & $0.578^{\mathrm{c}}$ & 1.4 & $0.049^{c}$ & 5.8 & $\underline{0.435^{\mathrm{c}}}$ & 5.0 \\
\hline $\begin{array}{l}\text { Melon } \\
\text { (Scion) }\end{array}$ & $\begin{array}{l}\text { Hybrid } \\
\text { London }\end{array}$ & $0.607^{\mathrm{a}}$ & 0.0 & $0.185^{\mathrm{a}}$ & 0.0 & $0.567^{\mathrm{a}}$ & 0.0 & $0.586^{\mathrm{a}}$ & 0.0 & $0.052^{\mathrm{a}}$ & 0.0 & $\underline{0.458}^{\mathrm{a}}$ & 0.0 \\
\hline
\end{tabular}

*Each value presented the mean of four replicates

Means in each column followed by the same letter(s) did not differ at $\mathrm{P} \leq 0.05$ according to Duncan`s multiple range tests

Grafted or ungrafted rootstocks i.e. Ferro RZ and Nun 6001 Squash No3, Flixel Fort, Super Shintosa, Bottle gourd, and Coplt were classified as tolerant hosts to $M$. incognita infection. Meanwhile, Pakistan loof was rated as a susceptible host. These results indicated that the use of tolerant rootstocks has great potential for improving nematode control in the absence of soil fumigants due to reduced nematode gall formation as reported by Siguenza et al. (2005), Kokalis-Burelle \& Rosskopf ( 2011), and Ayala-Doñas et al. (2020).

Data also indicate that grafting melon plants onto all the previous rootstocks gave the higher plant survival rate than the grafted melon plant onto Pakistani Loof rootstock or un-grafted melon plants during the two studied seasons. These results indicate that grafting melon plants onto all the previous tolerant rootstocks is an effective tool that may enable the susceptible melon scion to tolerate $M$. incognita which leads to an increase in the plant's survival rate compared to the un-grafted melon seedlings. This investigation is in the line with (Aslam et al., 2020; Guan \& Haseman, 2020).

The differences in plant survival rate may be attributed to rootstock vigor (Andrews \& Marquez, 1993; Lee, 1994; Lee et al., 1998; Oda, 1999; TrakaMavrona et al., 2000; Edelstein et al., 2004; Aslam et al., 2020). Also, these findings are in par with those of Tamil Selvi et al. (2013) who reported that the plant growth response to nematode infection varied according to the cultivated cucurbitaceous species and use of resistant rootstocks for grafting. 
They also added that the reduction in tested cultivars growth criteria due to $M$. incognita infection was obviously in fresh weights of either plant shoots or roots. Also, the uses of tolerant rootstocks to root-knot nematode for grafted melon plants are favorable for low-input sustainable horticulture. Therefore it should be a benefit to grow in areas with high root-knot nematode infestation (Jansea \& Van der Wurff, 2010; Thies et al., 2010; Al-Debei et al., 2012; Wilcken et al., 2013; Guan et al., 2014; Ito et al., 2014; Liu et al., 2015; Punithaveni et al., 2015; López-Gómez et al., 2016; Yankova et al., 2017; EL-Mesalamy et al., 2020). In this connection, Giné et al. (2017) reported that the rootstock (Cucurbita maxima $\mathrm{x}$ C. moschata) was no resistant to $M$. incognita.

A high reduction in the number of galls, females, and egg masses of $M$. incognita was indicated in tolerant rootstocks that agreed with results obtained by Youssef \& Amin (1997), Rather \& Siddiqui (2007), Amin et al. (2013), ELMesalamy et al. (2020) in using effective cucurbit rootstocks against $M$. incognita.

Tolerant rootstocks infected with $M$. incognita showed differences in their ability to stimulate peroxidase (PO) and polyphenol oxidase (PPO) activities, while, the susceptible Pakistani Loof rootstock showed the lowest activity of both PO and PPO. These results confirmed the findings of Marin et al. (2017) concerning melon rootstocks. Also, Ayala-Doñas et al. (2020) indicated the activity of peroxidases is increased after rootknot nematodes infection higher in resistant than susceptible cucurbits. Data also indicated the activity increase of total phenol which is at least in part responsible for defense mechanisms of the plant to nematodes.

Finally, it can be concluded that most of grafted and ungrafted rootstocks are tolerant of $M$. incognita infection compared to the highly susceptible melon cultivar. Thus grafting is an effective tool that may enable the susceptible melon scion to tolerate $M$. incognita which leads to an increase in the plant's survival rate compared to scion plants or un-grafted melon seedlings.

\section{Conclusions}

Grafting melon plants onto the previous tolerant cucurbit rootstocks has the potential to be an additional management tool for tolerance to root- knot nematode $M$. incognita diseases, improvement in plant growth parameters as well as increase peroxidase, polyphenol oxidase, and total phenol activities in plants.

Acknowledgement: The current study was conducted during the activity of the project "Grafting techniques to improve production and solve problems in the melon" supported by the Agriculture Development Program (ADP program) in Egypt. The authors gratefully acknowledge the support of the Agricultural Research Centre of Giza, Egypt who facilitated the study.

Conflict of interests: The authors declare no conflict of interest.

Authors contribution: DI and MZ suggested the plan of study and followed up on the carried-out work in addition to scripting the manuscript. DI executed the plan of work, analyzed the output data, and contributed in writing the manuscript.

Ethical approval: Not applicable.

Funding details: This work was supported by the Agriculture Development Program(ADP program), Ministry of Agriculture and Land Reclamation in Egypt under Grant "Grafting techniques to improve production and solve problems in the melon", Component of research and applied projects and extension campaigns.

\section{References}

Abd-Elgawad, M.M.M. (2008) The current status of phytonematode management in Egypt with special reference to applicable nematicides. Egyptian Journal of Agronematology, 6, 33-46.

Abd-Elgawad, M.M.M., Aboul-Eid, H.Z. (2001) Effects of oxamyi, insect nematodes and Serratia marcescens on a polyspecific nematode community and yield of tomato. Egyptian Journal of Agronematology, 5, 7989.

Al-Debei, H.S., Makhadmeh, I., Abu-Al Ruz, I., AlAbdallat, A.M., Ayad, J.Y., Al Amin, N. (2012) Influence of different rootstocks on growth and yield of cucumber (Cucumis sativus L.) under the impact of soil-borne pathogens in Jordan. Journal of Food, Agriculture \& Environment, 10(2), 343-349.

Amin, A.W. (1993) A new local race of the rootknot 
nematode Meloidogyne thamesi Chitwood in Chitwood, Specht \& Havis, 1952 in Hungary. Opuscula Zoologica Budapest XXVI, pp. 3-8.

Amin, A.W., Abd-El Wanis, M., Abdel Rahman, Tomader G. (2013) Evaluation of some cucurbitaceous rootstocks for resistance susceptibility to root- knot nematode and Fusarium wilt under greenhouse conditions. Egyptian Journal of Agriculture Research, 90(4), 1561-1577.

Andrews, P.K., Marquez, C.S. (1993) Graft incompatibility. Horticultural Reviews, 15, 183-218.

Aslam, W., Shahzad Noor, R., Hussain, F., Ameen, M., Saif Ullah, Chen, H. (2020) Evaluating morphological growth, yield, and postharvest fruit quality of cucumber (Cucumis Sativus L.) grafted on cucurbitaceous rootstocks. Agriculture, 10(101), $1-10$.

Ayala-Doñas, A., Cara-García, M., Talavera-Rubia, M., Verdejo-Lucas, S. (2020) Management of soilborne fungi and root-knot nematodes in cucurbits through breeding for resistance and grafting. Agronomy, 10(11), 1641; https://doi.org/10.3390/ agronomy 10111641

Biles, C.L., Martyn, R.D., Wilson, H.D. (1989) Isozymes and general proteins from various watermelon cultivars and tissue types. HortScience, 24, 810-812.

Byrd, D.W., Kirapatrick, T., Barker, K. (1983) An improved technique for clearing and staining plant tissues for detection nematodes. Journal of Nematology, 15(3), 142-143.

Canto- Saenz, M. (1983) The nature of resistance to $M$. incognita (Kofoid\&White, 1919) Chitwood, 1949, pp. 160-165. In Proc. Third Res \& Plann. Conf. on Root-knot Nematodes Meloidogyne Project, Lima, Peru, 233 pp.

Edelstein, M., Burger, Y., Horev, C., Porat, A., Meir, A., Cohen, R. (2004) Assessing the effect of genetic and anatomic variation of Cucurbiat rootstocks on vigour, survival and yield of grafted melons. Journal of Horticulture Science and Biotechnology, 79(3), 370-374.

EL-Mesalamy, A.F., Mahmoud, N.A., Anany, A.E., ElSagheer, A.M. (2020) Susceptibility of some plant cultivars cucumber and watermelon to root- kont nematode, Meloidogyne javanica under greenhouse conditions. Journal of Plant Protection and Pathology, Mansoura University, 11(3), 191-195.

Giannakou, I.O., Karpouzas, D.G. (2003) Alternatives to methyl bromide for root-knot nematode control. Pest Management Science, 59, 883-892.

Giné, A., González, C., Serrano, L., Sorribas, F.J. (2017) Population dynamics of Meloidogyne incognita on cucumber grafted onto the Cucurbita hybrid RS841 or ungrafted and yield losses under protected cultivation. Europian Journal of Plant Pathology, 148, 795-805.

Gomez, K.A., Gomez, A.A. (1984) "Statistical Procedures for Agriculture Research". $2^{\text {nd }}$ ed., June Wiley \& Sons.Inc. New Yourk, USA.

Goodey, J.B. (1957) "Laboratory Methods for Work with Plant and Soil Nematodes". Tech. Bull. No.2 Min. Agric. Fish Ed. London, p. 47.

Gu, X.F., Zhang, S.P., Zhang, S.Y., Wang, C.L. (2006) The screening of cucumber rootstocks resistant to southern root-knot nematode. China Vegetables, 2, 4-8.

Guan, W., Haseman, D. (2020) Rootstock evaluation for grafted cucumbers grown in high tunnels: yield and plant growth. Hortscience, 55(6), 914-919.

Guan, W., Zhao, X., Dickson, D.W., Mendes, M.L., Thies, J. (2014) Root-knot nematode resistance, yield, and fruit quality of specialty melons grafted onto Cucumis metulifer. Horticulture Science, 49(8), 1046-1051.

Hagitani, S., Toki, T. (1978) Studies on the use of star cucumber (Sicyos angulatus L.) as a rootstock for cucurbits. 2. Resistance to the root-knot nematode Meloidogyne incognita. Bulletin of Chiba Agricultural Experiment Station, 19, 25-30 (In Japanese with English summary).

Hassell, R.L., Memmott, F., Liere, D.G. (2008) Grafting Methods for Watermelon. Horticultural Science, 43(6), 1677-1679.

Hussey, R.S., Barker, K.R. (1973) A comparison on methods of collecting inocula of Meloidogyne spp. including a new technique. Plant Diseases Report, 57, 1925-1928

Ito, L.A., Gaion, L.A., Galatti, F.S., Braz, L.T., Santos, 
J.M. (2014) Resistance of cucurbit rootstocks to nematodes and grafting in melon. Horticultura Brasileira, 32, 297-302.

Jansea, J., van der Wurff, A.W.G. (2010) Suitable rootstocks for organically grown tomato and cucumber in relation to Meloidogyne spp. Acta Horticulture, 915, 117-124.

Kokalis-Burelle, N., Rosskopf, E.N. (2011) Microplot evaluation of rootstocks for control of Meloidogyne incognita on grafted tomato, muskmelon, and watermelon. Journal of Nematology, 43(3-4), 166171.

Lee, J.M. (1994) Cultivation of grafted vegetables I. Current status, grafting methods, and benefits. HortScience, 29(4), 235-239.

Lee J.M., Oda, M. (2003) Grafting of herbaceous vegetable and ornamental crops. Horticultural Reviews, 28, 61-125.

Lee, J.M., Bang, H. J., Ham, H.S. (1998) "Grafting of vegetables." J. Japanese Society for Horticultural Science, 67(6), 1098-1114.

Liu, B., Ren, J., Zhang, Y., An, J., Chen, M., Chen, M., Xu, C., Ren, H. (2015) A new grafted rootstock against root-knot nematode for cucumber, melon, and watermelon. Agronomy for Sustainable Development, 35, 251-259.

Liu, W., Xiang, C., Li, X., Wang, T., Lu, W. , Liu, Z., Gao, L., Zhang, W. (2020) Identification of long-distance transmissible mRNA between scion and rootstock in cucurbit seedling heterografts. International Journal of Molecular Sciences, 21, 5253, 1-22.

López-Gómez, M., Talavera, M., Verdejo-Lucas, S. (2016). Differential reproduction of Meloidogyne incognita and $M$. javanica in watermelon cultivars and cucurbit rootstocks. Plant Pathology, 65, 145153.

Marin, M.V., Santos, L.S., Gaion, L.A., Rabelo, H., Franco, C.A., Diniz, G.M. , Silva, E.H.C., Braz, L.T. (2017) Selection of resistant rootstocks to Meloidogyne enterolobii and M. incognita for okra (Abelmoschus esculentus L. Moench). Chilean Journal of Agricultural Research, 77(1), 58-64.

Miguel, A., Marsal, J.I., L'opez-Galarza, S., Maroto,
J.V., Tarazona, V., Bono, M. (2005) Comportamiento de portainjertos de sand'ia frente a nematodos. Phytoma-Espana, La revista profesional de sanidad vegetal, ISSN 1131-8988, № 175, 2006, págs. 20-24

Mukhtar, T., Kayani, M.Z., Hussain, M.A. (2013) Response of selected cucumber cultivars to Meloidogyne incognita. Crop Protection, 44, 13-17.

Oda, M. (1999) Grafting of vegetables to improve greenhouse production. Food and Fertilizer Tech. Center. www.agnet.org/library/eb/480/ Accessed Dec. 7, 2007.

Oda, M. (2002a) Grafting of vegetable crops. Science Report Agriculture \& Biological Science, Osaka Pref University, 53, pp. 1-5.

Oda, M. (2002b) Grafting of vegetable crops. Science Report Agriculture \& Biological Science, Osaka Pref University, 54, pp.49-72.

Paroussi, G.F., Bletsos, G.A., Bardas, J.A., Kouvelos, M., Klonari, A. (2007) Control of Fusarium and Verticillium wilt of watermelon by grafting and its effect on fruit yield and quality. Proc. IIIrd Balkan Symp. on Veg. and Potatoes. Acta Horticulture ISHS, 729, 281-285.

Penelope, P. (2008) Cucurbit Grafting. Critical Reviews in Plant Sciences, 27(1), ,50-74.

Punithaveni, V., Jansirani, P., Sivakumar, M. (2015) Screening of cucurbitaceous rootstocks and cucumber scions for root knot nematode resistance (Meloidogyne incognita Kofoid and White). Electronic Journal of Plant Breeding, 6(2), 486-492.

Rather, M.A., Siddiqui, M.A. (2007) Nematicidal effects of some botanicals against root-knot nematode, Meloidogyne javanica on tomato. International Journal of Plant Sciences, 2, 49-52.

Sasser, J.N., Eisenback, J.D., Carter, C.C. (1983) The International Meloidogyne Project-its goals and accomplishments. Annual Review of Phytopathology, 21, 271-288.

Siguenza, C., Schochow, M., Turini, T., Ploeg, A. (2005) Use of Cucumis metuliferus as a rootstock for melon to manage Meloidogyne incognita. Journal of Nematology, 37(3), 276-280.

Talavera, M., Sayadi, S., Chirosa-Ríos, M., Salmerón, 
T., Flor- Peregrín, E., Verdejo-Lucas, S. (2012) Perception of the impact of root-knot nematode induced diseases in horticultural protected crops of South-Eastern Spain. Nematology, 14, 517-527.

Tamil Selvi, N.A., Pugalendhi, L., Sivakumar, M. (2013) Screening of cucurbitaceous rootstocks against root knot nematode Meloidogyne incognita Kofoid and White. Asian Journal of Horticulture, 8(2), 720-725.

Taylor, A.L., Sasser, J.N. (1978) "Biology, Identification and Control of Root-Knot Nematodes (Meloidogyne spp.) Coop". Pub. Dept. Plant Pathology, North Carolina State University, and U.S. Agency Int. Dev., Raleigh, N.C. 111p.

Thakur, D., Savita (2020) Role of grafting in vegetable crops: A review. Journal of Pharmacognosy and Phytochemistry, 9(6), 1170-1174.

Thakur, S., Mehta, D.M., Thakur, R. (2020) Grafting in Vegetables - A New Technique. Research Today, 2(6), 489-492.

Thies, J.A., Ariss, J.J., Hassell, R.L., Olson, S., Kousik, C.S., Levi, A. (2010) Grafting for management of southern root-knot nematode, Meloidogyne incognita, in watermelon. Plant Diseases, 94, 11951199.

Traka-Mavrona, E., Koutsika-Sotiriou, M., Pritsa, T. (2000) Response of squash (Cucurbita spp.) as rootstock for melon (Cucumis melo L.). Scientia Horticulturae, 83, 353-362.

Wang, C., Roberts, P.A. (2006) A Fusarium wilt resistance gene in Gossypium barbadense and its effect on root-knot nematode-wilt disease complex. Phytopathology, 96(7), 727-734.

Wilcken, S.R.S., Rosa, J.M.O., Westerich, J.N., Garcia, M.J.M., Cardoso, A.I.I. (2013) Reproduction of Meloidogyne enterolobii in rootstocks and cucumber hybrids. Horticultura Brasileira, 31, 618-621.

Yankova, V., Markova, D., Velkov, N., Masheva, S. (2017) Screening of cucurbitaceous rootstocks against root-knot nematodes (Meloidogyne spp.) and soilborne pathogens (Fusarium spp. and Pythium spp.). Agricultural Science and Technology, 9(1), 62-66.

Yetısır, H., Sari, N. (2003) Effect of hypocotyl morphology on survival rate and growth of watermelon seedlings grafted on rootstocks with different emergence performance at various temperatures. Turkish Journal of Agriculture and Forestry, 28, 231-237.

Youssef, M.M.A, Amin, W.A. (1997) Effect of soil amendment in the control of Meloidogyne javanica and Rotylechulus reniformis infection on cowpea. Pakistan Journal of Nematology, 15, 55-63.

\section{Meloidogyne استجابة أصول القرعيات لمقاومة نيماتودا تعقد الجذور ميليدوجينى اكوجنيتا incognita

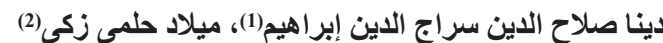

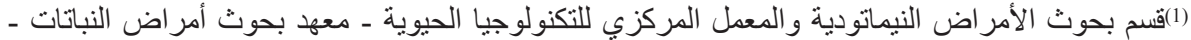

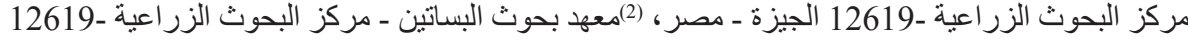

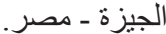

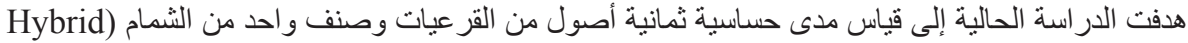

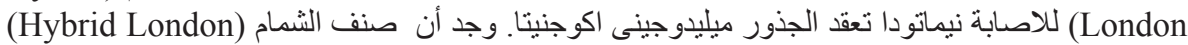

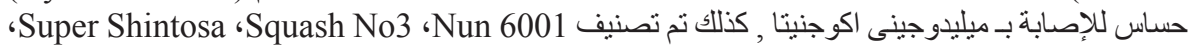
Pakistani Coplt ،Ferro RZ ،Flixel Fort

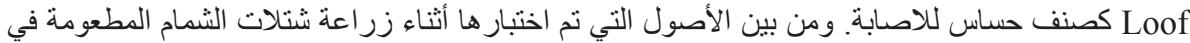

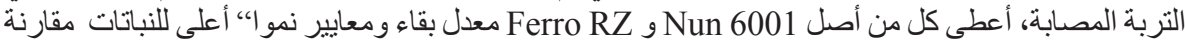

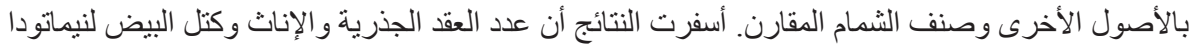

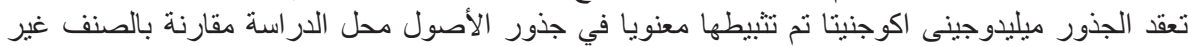

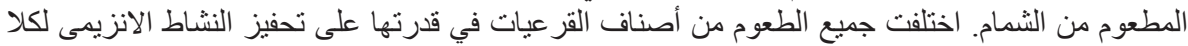

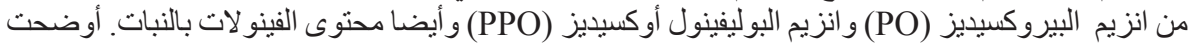

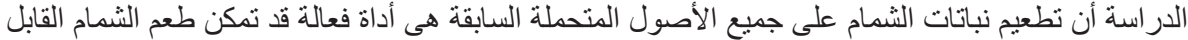

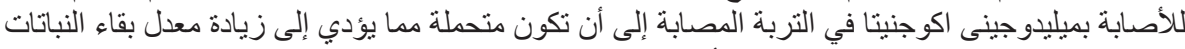

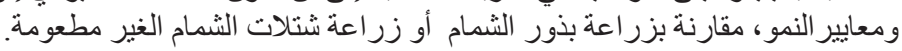

